\title{
Herpes simplex virus encephalitis: clinical features and residual damage
}

\author{
J. M. OXBURY* \\ F. O. MacCallum \\ Departments of Clinical Neurology and Virology, Oxford University and United Oxford Hospitals, Oxford
}

HERPES simplex virus encephalitis (HSVE) presents to the clinician as a comparatively rare acute neurological disease with a grave prognosis. However, there is now a reasonable probability that effective therapeutic agents may soon be available. If they are to be used with maximum benefit it is necessary that we should be able to diagnose the disease rapidly in the early stages. Likewise, if they are to be assessed rationally it is important that we should know the natural history of the disease. For these reasons we have reviewed the case histories of sixteen patients with HSVE seen in the Oxford Neurology and Neurosurgery Departments during 1959-1971. We have included only patients diagnosed by identification of virus in the brain and/or by finding the histological features of acute necrotizing encephalitis. The present communication briefly summarizes the findings, with particular reference to the clinical features and the final outcome; a detailed report will be published in due course.

There were ten males and six females, aged 11-65 years with a median of 42 years. Seven patients were admitted direct; the other nine were transferred from their local hospital. The length of history prior to the initial admission to hospital was usually about 1 week, but it varied from 2 days to several weeks. All sixteen patients had complained of abnormal headache, which was sometimes severe, and this symptom had sometimes been present for several weeks, suggesting a diagnosis of cerebral tumour. Other symptoms included: mental abnormalities in ten (with confusion, disorientation, bizarre behaviour and sometimes hallucinations); seizures in five; severe dysphasia in four; and focal sensory/motor symptoms in one. Examination at the time of admission revealed: meningism in nine; focal motor, sensory or visual signs in eight; confusion, disorientation or stupor in seven; and severe dysphasia, commonly jargon dysphasia, in four. Although only two were overtly comatose on admission, many others subsequently deteriorated to coma. One patient (Case No. 7 in Table 3) was admitted as a case of pyrexia of unknown aetiology without neurological

\footnotetext{
* Reprint requests to: J. M. Oxbury, Oxford University Department of Clinical Neurology, The Churchill Hospital, Oxford.
}

signs; she subsequently deteriorated to coma before making a good, but not complete, recovery.

Likewise the findings at the first lumbar puncture were very variable. Fourteen patients had their CSF obtained by this route before any specific medication had been given and before any sort of neurosurgical interference. At this first examination the CSF was normal (protein not $>60 \mathrm{mg} / 100 \mathrm{ml}$, and cells $<8$ / $\mathrm{mm}^{3}$ ) in four cases. The finding of a normal CSF is no indication of a mild infection; two patients died of fulminating encephalitis within a few days of such a finding and, at necropsy, virus was cultured from widespread areas of the brain. In six patients the initial CSF contained an elevated protein content $(90-240 \mathrm{mg} / 100 \mathrm{ml})$ and a pleocytosis (62-950 white cells $\left./ \mathrm{mm}^{3}\right)$; in the other four patients there was a pleocytosis (66-400 white cells $/ \mathrm{mm}^{3}$ ) without any elevation of the protein. The pleocytosis was most frequently a mixture of lymphocytes $\left(60-900 / \mathrm{mm}^{3}\right)$ and polymorphs $\left(6-220 / \mathrm{mm}^{3}\right)$, but in three cases it consisted of lymphocytes only $\left(62-200 / \mathrm{mm}^{3}\right)$. The presence of red blood corpuscles in the CSF was very unusual.

Brain biopsy was carried out in all cases, and it established the diagnosis in fifteen. In the one other patient, admitted in 1959, virological studies were not performed, the histological picture was nonspecific, and it was only at necropsy that the changes of acute necrotizing encephalitis were found. Herpes simplex virus was identified in the biopsies of thirteen patients, the two others being negative, and the histological picture of acute necrotizing encephalitis was found in nine, including the two cases where attempts to isolate the virus were negative. The finding of intranuclear inclusion bodies was unusual in biopsy specimens but common in necropsy material following death in the acute phase.

Six patients died within 1 month of admission to hospital and, of the ten survivors, six were severely disabled such that they were entirely dependent on the care of others for the rest of their lives. Four patients were treated with iodo-deoxyuridine; these cases have been reported by Buckley \& MacCallum (1967), and by Tomlinson \& MacCallum (1970). Two others were treated with cytosine arabinoside. The relationship between treatment and outcome is shown in Table 1. It has not been possible to corre- 
TABLE 1. Outcome in HSVE (sixteen cases)

\begin{tabular}{lcccc}
\hline & Untreated & IDU & Ara-C & Total \\
\hline Dead in 1 month & 3 & 3 & 0 & 6 \\
Survived 1 month & 4 & 1 & 1 & 6 \\
$\quad$ Totally dependent & 1 & 0 & 0 & 1 \\
Partial independence (unable to work) & 2 & 0 & 1 & 3 \\
Mild impairment & 10 & 4 & 2 & 16 \\
\hline Total & & & \\
\hline
\end{tabular}

late the outcome with the nature of the patients' symptoms or physical signs on admission to hospital, with the development of coma or with the nature of the CSF contents. Nor is there any clear indication that medication was of value, but the numbers are far too small to draw any definite conclusion. A factor that may be important is severe brain swelling. At biopsy the brains of four patients were found to be severely swollen. Three of them died during the acute phase. The fourth, who survived, was given a surgical decompression. There was no obvious relationship between the presence of severe brain swelling and the previous duration of the illness.

Six of the ten survivors were severely disabled and five of these six are now dead (Table 2). All six had some degree of generalized dementia. In addition, two patients had profound jargon dysphasia, and one had a severe amnesic syndrome of the type classically associated with bilateral hippocampal damage. The latter patient (Case No. 1) had prolonged coma lasting approximately 3 weeks during the acute phase, with severe brain swelling treated by sub-temporal decompression. For a long time she was very apathetic and severely retarded but, within 18 months, she was able to feed herself and walk about. She had become very garrulous and disinhibited in her conversation, which usually bore no relationship to fact. She was also inclined to eat paper and possibly other objects. Formal assessment of her psychological state revealed that although her IQ was only moderately deteriorated (WAIS full scale score 82 , with verbal 93 and performance 70 in a woman whose premorbid intelligence was probably average), she had a disproportionately severe disturbance of shortterm memory such that she was unable to retain new material for even a few minutes. She died of bronchopneumonia 4 years after the onset of her illness. Dr
David Oppenheimer examined her brain at necropsy and reported extensive bilateral destruction of the anterior and medial portions of the temporal lobes, and of the orbital-frontal cortex and the cingulate gyri. There was degeneration of the fornix system bilaterally, and the mammillary bodies and dorsomedial thalamic nuclei were shrunken. In some ways she resembled the cases reported by Rose \& Symonds (1960). Her inclination to eat paper was reminiscent of the syndrome described by Kluver \& Bucy (1939). This compulsion to examine objects orally was extreme in Case No. 3 who even had to be prevented from eating his faeces. Necropsy examination of his brain revealed bilateral destruction of the temporal lobes and of the orbital frontal cortex even more extensive than in Case No. 1.

The findings in both these cases are consistent with the generally accepted distribution of the cerebrab destruction in HSVE, there being predominant involvement of the orbital frontal cortex, temporaf lobes, hippocampal gyri and fornix system. Although the extent of the destruction in the two cerebral hemispheres was not absolutely symmetrical, both were so damaged that anything approaching normal behaviour would have been quite impossible. Fewer details are available for Case Nos. 2, 4 and 5. They all returned to their local hospitals and were not seen again in Oxford nor, as far as we know, were their brains examined at necropsy. However, it seems likely that they too had extensive bilateral cerebral damage. It is too early yet to say what the final outcome will be in Case No. 6. At present her main disability is severe and incapacitating jargon dysphasia but, in addition, her general behaviour is disorganized to an extent which makes it likely that there is significant damage in both frontal lobes.

Hughes (1969) has pointed out that in HSVE the

TABLE 2. HSVE survivors (six totally dependent cases)

\begin{tabular}{|c|c|c|c|c|c|c|c|}
\hline Case no. & $\begin{array}{c}\text { Age at } \\
\text { onset } \\
\text { (years) }\end{array}$ & $\begin{array}{c}\text { Survival } \\
\text { (D, dead; } \\
\text { A, alive) }\end{array}$ & $\begin{array}{l}\text { Generalized } \\
\text { dementia }\end{array}$ & $\begin{array}{c}\text { Severe } \\
\text { amnesic } \\
\text { syndrome }\end{array}$ & Dysphasia & Tetraparesis & Epilepsy \\
\hline $\begin{array}{l}1 \\
2 \\
3 \\
4 \\
5 \\
6\end{array}$ & $\begin{array}{l}59 \\
42 \\
39 \\
41 \\
62 \\
50\end{array}$ & $\begin{array}{l}\text { D } 4 \text { years } \\
\text { D } 21 \text { months } \\
\text { D } 15 \text { months } \\
\text { D } 12 \text { months } \\
\text { D } 7 \text { months } \\
\text { A } 2 \text { months }\end{array}$ & $\begin{array}{c}+ \\
+++ \\
+++ \\
+ \\
++ \\
++\end{array}$ & $++t$ & $\begin{array}{l}\text { jargon } \\
\text { jargon }\end{array}$ & $\begin{array}{c}++ \\
+ \\
++\end{array}$ & + \\
\hline
\end{tabular}


TABLE 3. HSVE survivors (three with minimal defect)

\begin{tabular}{cccl}
\hline Case no. & $\begin{array}{c}\text { Age at } \\
\text { onset } \\
\text { (years) }\end{array}$ & Date of onset & \multicolumn{1}{c}{ Residual deficit } \\
\hline 7 & 11 & September 1962 & $\begin{array}{l}\text { Personality change } \\
\text { Mild learning defect } \\
\text { R. hemisphere defects } \\
\text { Mild dysphasia } \\
\text { Mild personality change } \\
\text { Mild visuo-spatial and non- } \\
\text { verbal memory defect }\end{array}$ \\
\hline 9 & 65 & May 1969 & June 1971 \\
\hline
\end{tabular}

cerebral hemispheres are often affected asymmetrically, the destruction in one being considerably greater than that in the other. So, it is possible that patients who recover to be left with only minor disabilities may have the disease process largely restricted to one cerebral hemisphere; although even this could have catastrophic affects if it destroyed a particularly eloquent area such as the posterior temporal and inferior parietal cortex on the dominant side.

Tomlinson \& MacCallum (1970) concluded from their review of a number of reported series of HSVE that $23 \%$ of patients were claimed to have made a 'full recovery'. It is extremely rare for this claim to be supported by any evidence derived from detailed neuropsychological testing. This is, perhaps, surprising in a disease whose main residua are behavioural. In our series of sixteen patients none is normal, although three have been left with only relatively minor disturbances (Table 3 ), and their features suggest that in each of them the disease must have been largely restricted to one cerebral hemisphere. This can be illustrated by a few salient points from the clinical history of Case No. 9. On admission he was obtunded but rousable and could speak rationally even though he could not co-operate properly during the examination; there was neck stiffness, a left hemiparesis, and probably a left hemianopia. The right carotid arteriogram showed considerable shift from right to left and, in the right temporal region, a vascular pattern recognized by $\mathrm{Dr}$ Philip Sheldon as suggestive of acute necrotizing encephalitis. Herpes simplex virus was isolated from a biopsy of the area even though the histological appearances were non-specific. Following a period of coma, his level of consciousness improved and in the early stages he had a mild left hemiparesis. There had been no clinical evidence of left hemisphere disease. Nor was any revealed by detailed neuropsychological testing as early as 6 weeks after admission; in particular his verbal intelligence and verbal memory were entirely normal. This contrasted with his severe psychological disturbances attributable to right hemisphere damage. Over the next few months these disturbances diminished considerably but they were still present at his most recent examination. Much the same is true of Case No. 7 who, 9 years after her illness, has been passed as 'normal' but still has prosopagnosia and a marked disorder of topographical memory. The disturbances are such that she has had to obtain protected employment on the Disabled Persons Register even though she is a pretty well-spoken girl with no physical defect and a Wechsler IQ of 105!

It is important that the natural history of HSVE should be clearly delineated, not least so that the proper place of effective treatment can be determined when, and if, it becomes available. We conclude that it is a disease associated with a very high incidence of permanent disability and death. Although a survey of the literature (Tomlinson \& MacCallum, 1970) indicated claims of full recovery in $23 \%$ of cases, it is doubtful whether such a high figure would be substantiated if strict criteria of assessment, including proper neuropsychological testing, were applied to proved cases of HSVE of the type currently under discussion. Whether or not there are minor or 'subclinical' infections of the brain, such as might result in psychopathy (Cleobury et al., 1971) is another matter.

\section{References}

Buckley, T. F. \& MacCallum, F. O. (1967) Herpes simplex virus encephalitis treated with idoxuridine British Medical Journal, 2, 419.

Cleobury, J. F., Skinner, G R. B., Thouless, M. E. \& WILDY, P. (1971) Association between psychopathic disorder and serum antibody to herpes simplex virus (type 1). British Medical Journal, 1, 438.

Hughes, J. T. (1969) Pathology of herpes simplex encephalitis. In: Virus Diseases and the Nervous System (Ed. by C W. M. Whitty, J. T. Hughes and F. O. MacCallum). Blackwell Scientific Publications, Oxford.

Kluver, H. \& Bucy, P. C. (1939) Preliminary analysis of functions of the temporal lobe in monkeys. Archives of Neurology and Psychiatry, 42, 979.

Rose, F. C. \& Symonds, C. P. (1960) Persistent memory defect following encephalitis. Brain, 83, 195.

Tomlinson, A. H. \& MacCallum, F. O. (1970) The effect of iodo-deoxyuridine on herpes simplex virus encephalitis in animals and man. Annals of the New York Academy of Sciences, 173, 20. 